\title{
Moderate Red Wine Intake in Secondary Prevention for Patients with Cardiovascular Disease
}

\author{
Jean Pierre Rifler*1,2 Bernard Hudelot ${ }^{3}$ and Norbert Latruffe ${ }^{1}$ \\ ${ }^{1}$ INSERM UMR 866 - LBMN, France \\ ${ }^{2}$ C.H. Montbard, France
}

${ }^{3}$ Domaine Montmain, France

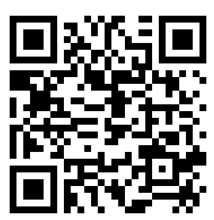

*Corresponding author: Jean Pierre Rifler, INSERM UMR 866 - LBMN, University of Burgundy, 6, bd Gabriel, 21000 Dijon, C.H. Montbard,21500 Montbard, France

\begin{tabular}{|c|c|}
\hline ARTICLE INFO & ABSTRACT \\
\hline Received: 蔧 October 21, 2019 & Citation: Jean Pierre Rifler, Bernard Hudelot, Norbert Latruffe. Moderate Red Wine \\
\hline Published: 幽 October 29, 2019 & $\begin{array}{l}\text { Intake in Secondary Prevention for Patients with Cardiovascular Disease. Biomed J Sci \& } \\
\text { Tech Res 22(2)-2019. BJSTR. MS.ID.003734. }\end{array}$ \\
\hline
\end{tabular}

\section{Introduction}

The cardioprotective effect of moderate and regular wine consumption in primary prevention has been well documented.
The goal of the present investigation was to explore the possible benefits of wine intake on secondary prevention in patients with cardiovascular disease (Figure 1) [1].

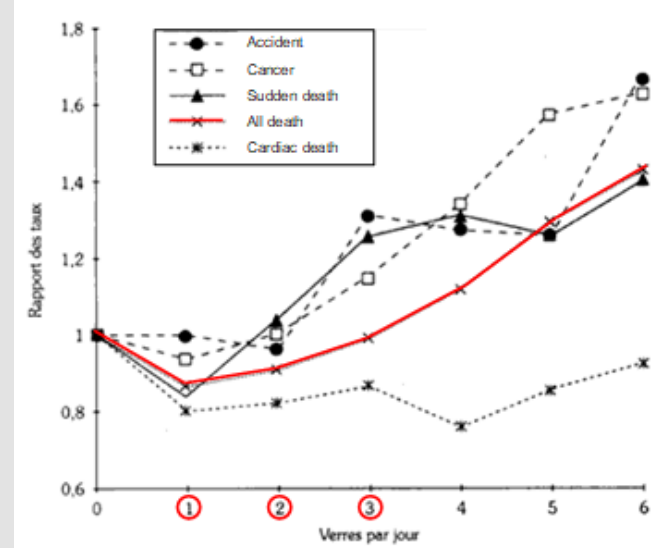

Ellison R.C. - Cheers. Epidemiology, 1990, 1, 337-339.

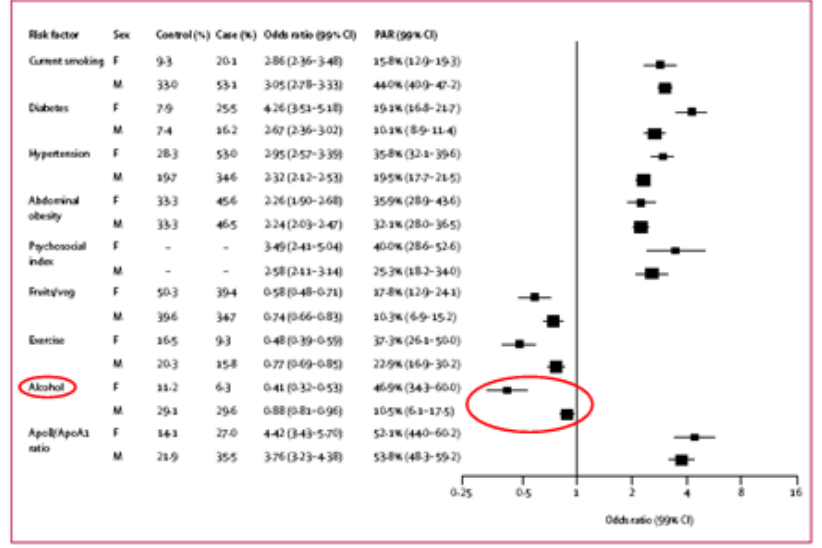
YUSUF S. Efect of po ten tallyymodifiable risk factors a ssociated with myocardial

Figure 1.

Materials and Methods

\section{Clinical Protocol}

Two randomised groups of early post myocardial infarction patients were compared: one receiving daily 2 x $125 \mathrm{~mL}$ of red wine $^{* *}(n=18)$, the other water $(n=15)$.

\section{Blood Parameters Measurement}

Total cholesterol, LDL, HDL and antioxidant status (Figure 2).

\section{Blood Anti-Oxidant Status}

KRL test, based on the hemolysis induced by radical attack, allows to measure the overall blood antiradical resistance. 
Antioxidant defenses contribute to maintain the membrane integrity and function of cells subjected to a radical attack, up to hemolysis. The resistance of blood at the radical attack is expressed when $50 \%$ of blood cells are lysed $\left(\mathrm{T}_{1} / 2\right.$ minutes).

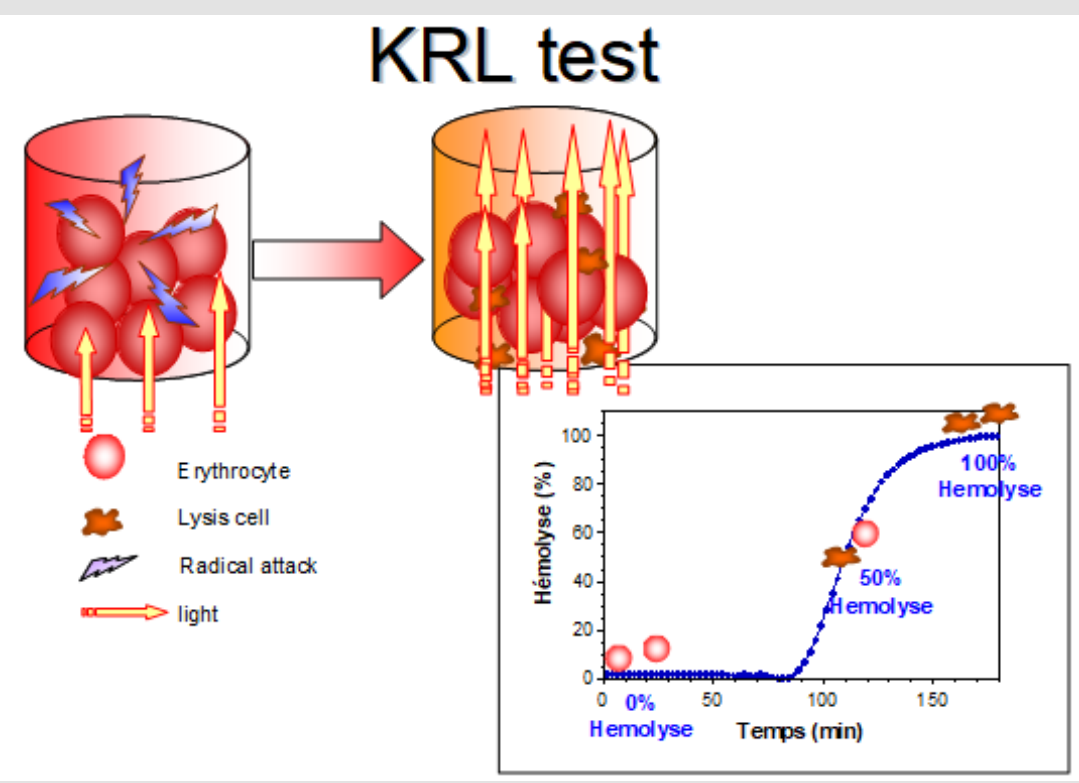

Figure 2.

\section{Results}

\section{Anti-Oxidant Level}

For wine drinkers the half hemolysis mean time is $84.74+$ /3.82 at day $0 ; 87.06+/-5.50$ at D14 $(\mathrm{p}<0.009)$. For the abstinent, the averages are $85.63+/-6.31$ at day 0 and $85.34+/-5.41$ at D14. The differences were significant only for the red wine group (Figure 3).

\section{Evolution of Lipid Profile}

Wine group had a significant LDL $(\mathrm{p}<0.02)$, total cholesterol $(p<0.04)$ and triacylglycerol $(p<0.05)$ decrease in only 2 weeks. For the abstinent group, total cholesterol and LDL cholesterol increased but not significantly; compensated by a significant increase in HDL.
The antioxidant power of serum did not increase, so the increase of LDL leads to an increase of oxidized LDL and consequently deposits of atherosclerotic plaque in the arteries (Figures $4 \& 5$ ).

\section{Conclusion}

These results suggest that the antiradical effect provided by the Mediterranean diet is only effective if the red wine is an integral part of the program. Lipidic profile is also benefically modified by this red wine diet.

The present investigation demonstrates the advantage of moderated wine intake on secondary prevention in patients with cardiovascular disease (Figure 6).
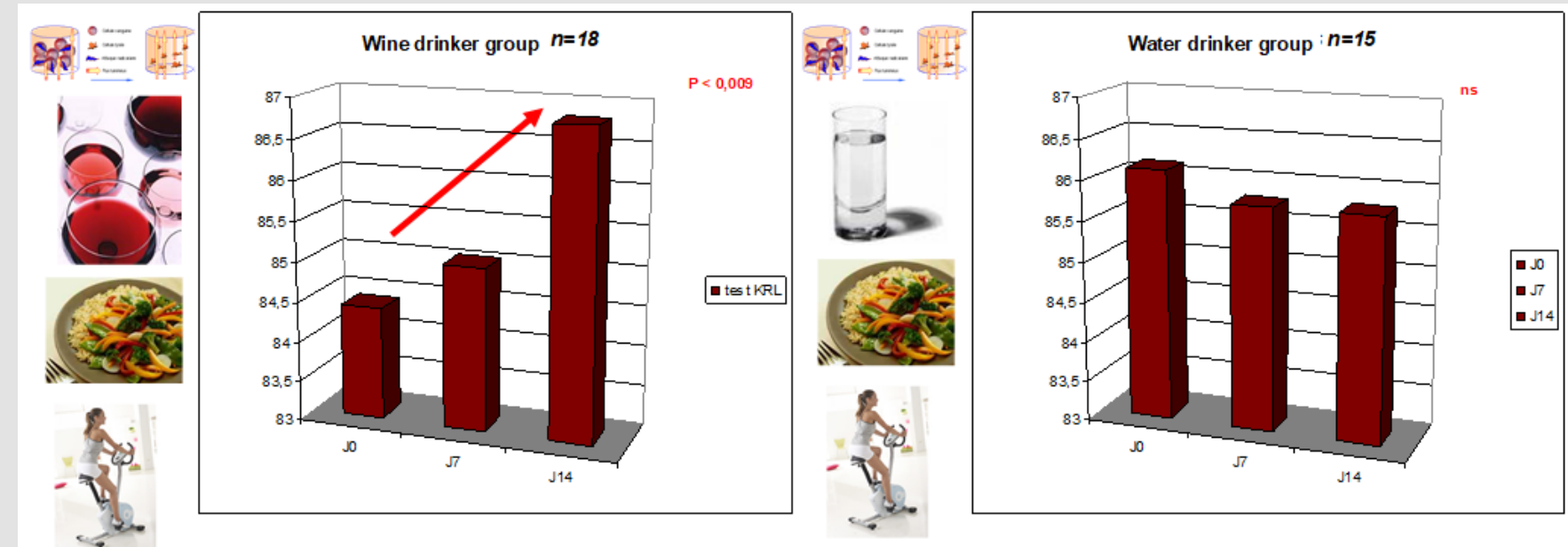

Figure 3. 

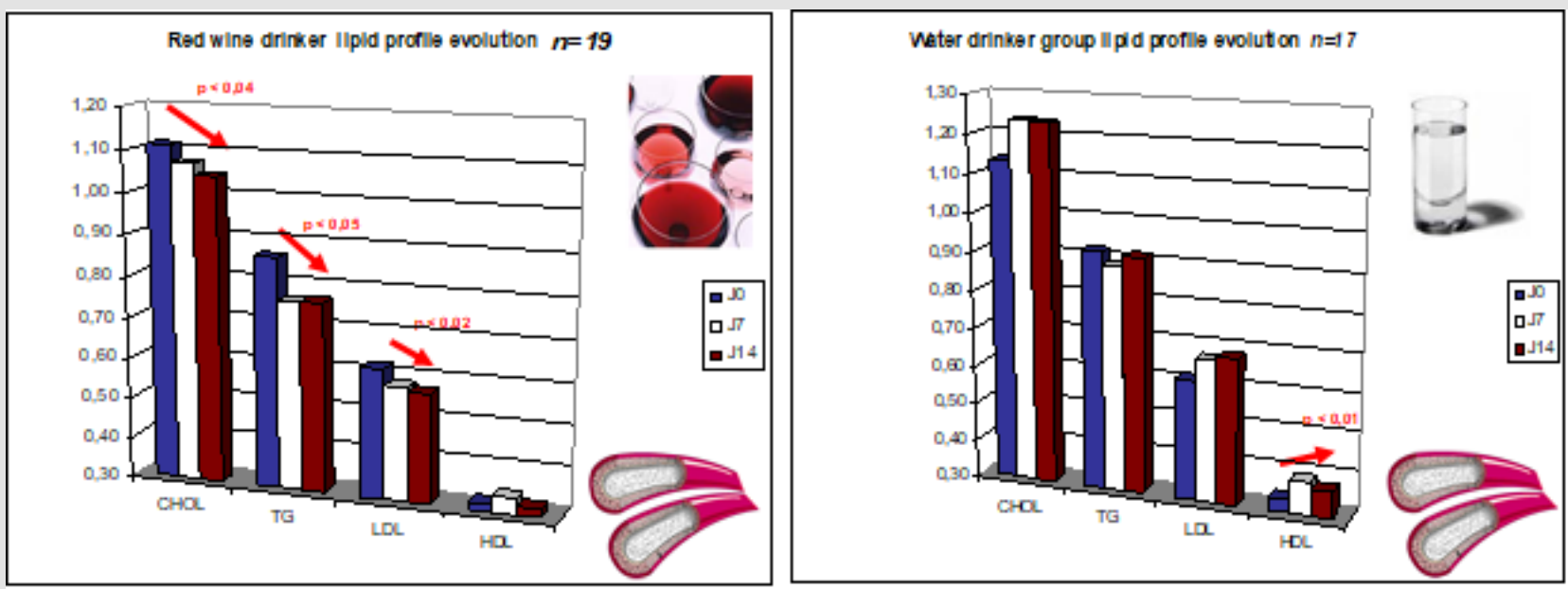

Figure 4.
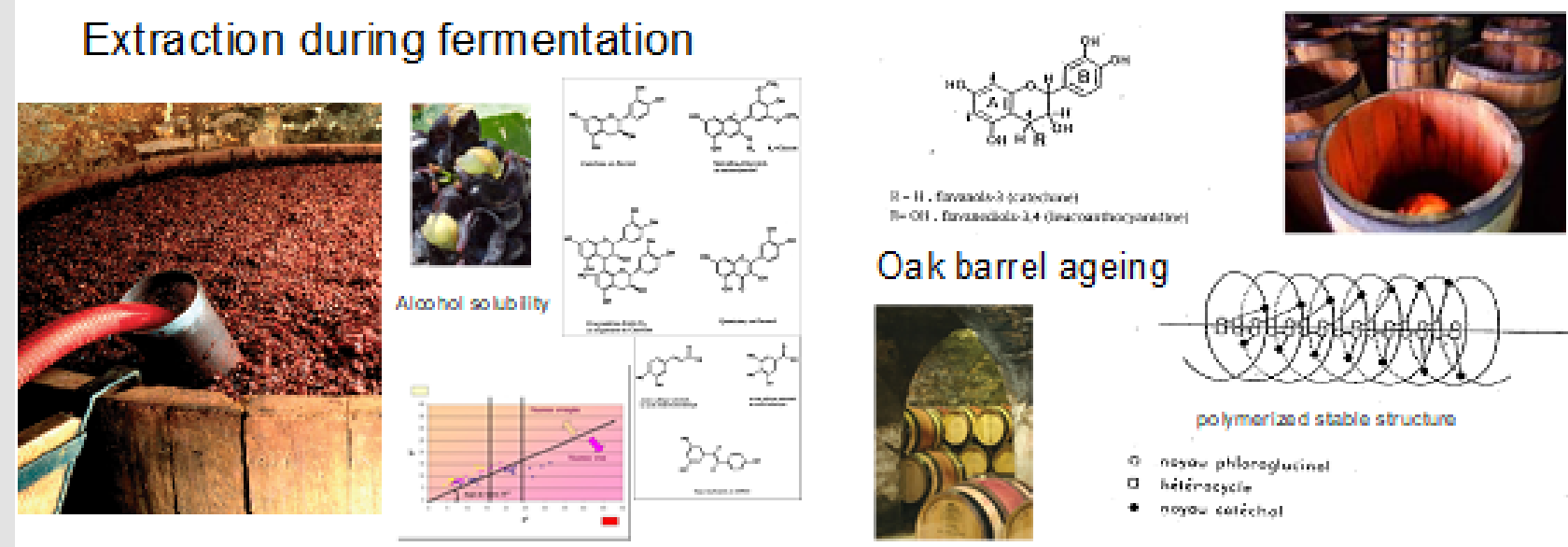

Oak barrel ageing

Figure 5.
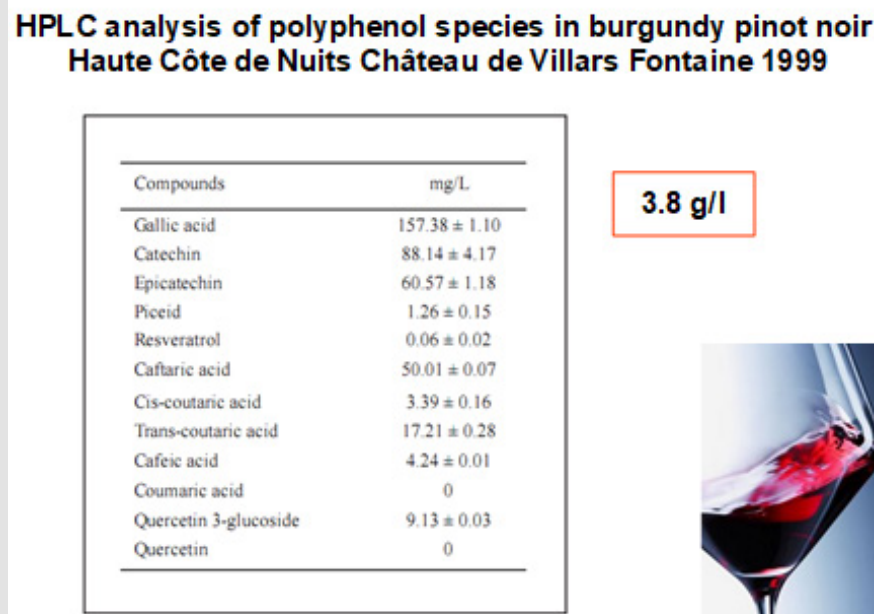

C analysis of polyphenol species in burgundy pinot
Haute Côte de Nuits Château de Villars Fontaine 1999

\begin{tabular}{lc|}
\hline & \\
\hline Compounds & $\mathrm{mg} \mathrm{L}$ \\
\hline Gallic acid & $157.38 \pm 1.10$ \\
Catechin & $88.14 \pm 4.17$ \\
Epicatechin & $60.57 \pm 1.18$ \\
Piceid & $1.26 \pm 0.15$ \\
Resveratrol & $0.06 \pm 0.02$ \\
Caftaric acid & $50.01 \pm 0.07$ \\
Cis-coutaric acid & $3.39 \pm 0.16$ \\
Trans-coutaric acid & $17.21 \pm 0.28$ \\
Cafeic acid & $4.24 \pm 0.01$ \\
Coumaric acid & 0 \\
Quercetin 3-glucoside & $9.13 \pm 0.03$ \\
Quercetin & 0 \\
\hline
\end{tabular}
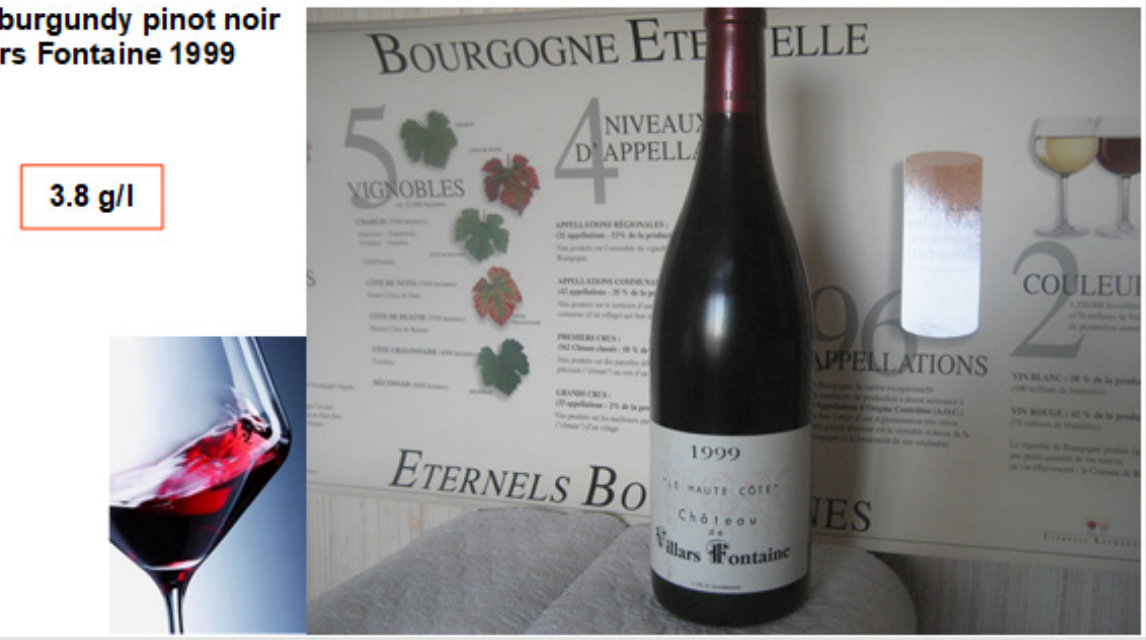

Figure 6: ${ }^{* *}$ Red wine used in the study.

\section{References}

1. Rifler JP, Lorcerie F, Durand P, Delmas D, Ragot K, et al. (2012) A moderate red wine intake improves blood lipid parameters and erythrocytes membrane fluidity in post myocardial infarct patients. Molecular Nutrition \& Food Research 56(2): 345-353. 
ISSN: 2574-1241

DOI: 10.26717/BJSTR.2019.22.003734

Jean Pierre Rifler. Biomed J Sci \& Tech Res

(c) (P) This work is licensed under Creative

Submission Link: https://biomedres.us/submit-manuscript.php

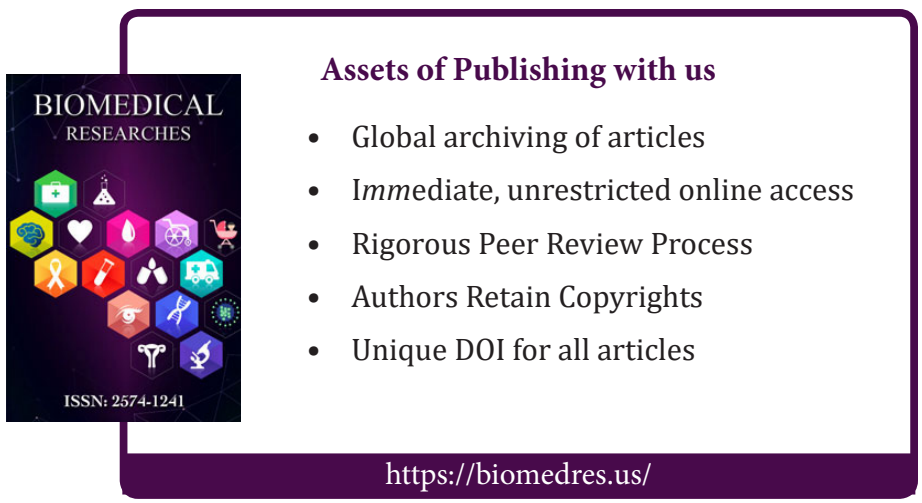

